\title{
PEMIKIRAN METODOLOGIS A. MUKTI ALI TENTANG PENELITIAN AGAMA
}

\author{
Rahmadi \\ Fakultas Ushuluddin dan Humaniora \\ IAIN Antasari Banjarmasin
}

Diterima tanggal 8 Mei 2015 / Disetujui tanggal 15 Juni 2015

\begin{abstract}
In Indonesia, it will be said that A.Mukti Ali is a pioneer in introducing religious studies. A.Mukti Ali realized that religious studies did not only need the scientific methods but they must also integrate with social approaches. He thought religious studies should be conducted objectively without involving the apologists-polemical element as a basic concept. In fact, the use of the scientific method, social sciences, and objective attitude do not be certainly enough to understand religious phenomenon, despite religious reflection must be involved and researchers must give their views too. All components must be synthesized in order to produce a holistic and integral assessment of religious phenomenon. The integrated components that needed in studying religious phenomenon is what be called by Mukti Ali as a scientific approach-cumdoctrinaire. This writing will discussed about A.Mukti Ali's thoughts in the field of religious studies.
\end{abstract}

Kata Kunci: Metode Ilmiah, Penelitian, Agama, Scientific-cum-Doctrinaire

\section{Pendahuluan}

Pada dekade 60-an, saat menjadi dosen perbandingan agama di IAIN Yogyakarta, A. Mukti Ali (1923-2004) mengamati beberapa kelemahan dalam tradisi akademik di IAIN. Setidaknya, ada tiga kelemahan yang menjadi keprihatinannya, yaitu kurangnya semangat keilmuan di kalangan pengajar dan mahasiswa, kurangnya penguasaan bahasa asing, dan kurangnya penguasaan metodologi. Kelemahan-kelemahan ini kemudian mendorong Mukti Ali untuk mengambil sejumlah kebijakan untuk mengatasi problem ini ketika ia menjabat sebagai menteri agama pada dekade 70 -an. Di antara program yang digagasnya untuk mengatasi kelemahan itu, terutama kelemahan metodologi, adalah membuka Post Graduate Course (PGC) ${ }^{1}$ yang masa belajarnya selama tiga bulan, setelah itu diteruskan dengan Program Studi Purna Sarjana (SPS) yang lama belajarnya selama lebih kurang sembilan bulan. Kemudian untuk memprakarsai kajian empiris dalam kajian agama, Mukti Ali juga menyelenggarakan Program Latihan Penelitian Agama (PLPA). ${ }^{2}$ PGC dan SPS dilaksanakan dari tahun 1971 hingga 1977, semuanya pada masa kepemimpinan Mukti Ali sebagai menteri agama, sementara PLPA dilaksanakan sejak tahun 1976/1977. ${ }^{3}$

${ }^{1}$ PGC pertama diselenggarakan pada tahun 1971 selama tiga bulan di IAIN Yogyakarta. Mata kuliah PGC (1971-1973) adalah Ilmu Perbandingan Agama, Fiqih, Ilmu Pendidikan, Ilmu Tafsir, Ilmu Hadis dan Metodologi Penelitian Sosial dan Agama. A. Singgih Basuki, Pemikiran Keagamaan A. Mukti Ali (Yogyakarta: Suka Press, 2013), 84.

${ }^{2}$ Waryani Fajar Riyanto, Integrasi-Interkoneksi Keilmuan: Biografi Intelektual M. Amin Abdullah (1953-...) Person, Knowledge, and Institution (Buku Pertama) (Yogyakarta: Suka Press, 2013), 635-636 dan 639-640.

${ }^{3}$ SPS diselenggarakan sebanyak tujuh angkatan yang diikuti oleh dosen-dosen IAIN dari seluruh Indonesia. Ada tiga mata pelajaran inti yang menjadi titik tekan SPS terutama pada tahun 1974 hingga 1976 yaitu Sejarah, Filsafat dan Metode Penelitian Sosial dan Agama. Mata pelajaran lainnya adalah Ilmu Perbandingan Agama, Fiqih, Pendidikan, Tafsir, pengajaran Bahasa Arab (kelimanya dari tahun 1971-1973), Alam Pikiran Modern dalam Islam, Ijtihad dan Bermazhab, dan Aliran Kebatinan 
Di samping menyelenggarakan program PGC/SPS dan PLPA, Mukti Ali juga aktif dalam memperkaya dan memperluas wawasan metodologis di kalangan akademisi perguruan tinggi Islam melalui sejumlah tulisannya tentang metode ilmiah dalam studi agama baik dengan tema metodologi Ilmu Perbandingan Agama, metodologi penelitian agama maupun dengan tema metode memahami Islam. Ia merupakan salah satu tokoh penting yang memperkenalkan metode ilmiah-empiris di samping metode doktriner dalam studi agama dan studi Islam. Pemikiran metodologisnya mampu mengurangi tradisi normatif yang kuat dalam studi agama di perguruan tinggi Islam dan mendorongnya ke arah kajian empiris terhadap fenomena keagamaan. Sebaliknya, ia juga mengusulkan agar kajian ilmiahempiris menyertakan kajian normatif-doktriner. Inilah yang menjadi gagasan metodologis utamanya yaitu metode sintesis atau populer dikenal dengan nama pendekatan scientific-cum-doctriner.

Mengingat posisi penting Mukti Ali dalam dinamika sejarah pemikiran metodologis dalam studi agama dan studi Islam di Indonesia, ${ }^{4}$ dalam tulisan ini akan dikemukakan sejumlah kontribusi pemikirannya mengenai aspek metodologi dalam penelitian agama yang telah dikemukakannya sejak tahun 1964 melalui sejumlah tulisan atau buku yang telah dipublikasikan.

\section{Biografi Singkat dan Karya Intelektual A. Mukti Ali}

Abdul Mukti Ali lahir di Cepu tanggal 23 Agustus 1923. Dia merupakan anak kelima dari tujuh bersaudara.Nama kecilnya adalah Boedjono. Oleh gurunya di Pesantren Termas, KH. Hamid, nama Boedjono kemudian diganti menjadi Abdul Mukti, kemudian sang ayah, H. Abu Ali, mengusulkan penambahan nama Ali di belakang nama barunya sehingga menjadi Abdul Mukti Ali. Nama ini secara resmi digunakan sejak tahun $1943 .^{5}$

Pada usia 7 dan 8 tahun (1931) Mukti Ali mendaftar di sekolah Belanda HIS dan mendaftar juga di madrasah diniyah di Cepu. Ia menyelesaikan pendidikannya di kedua sekolah ini sekitar tahun 1939 atau 1940. Tahun 1940, ia menempuh pendidikan di Pesantren Termas, Kediri. Ia juga belajar secara singkat ke beberapa pesantren lain seperti Tebu Ireng, Rembang, Lasem dan Padangan di Jawa Timur. ${ }^{6}$

Ketika belajar di Termas ia sempat mengikuti kelompok pergerakan yang kemudian menjadi barisan militer Hizbullah dan kemudian bergabung dengan Masyumi. Karena keterlibatannya di militer Hizbullah inilah yang membuatnya sempat ingin menjadi tentara dan meminta izin kepada kedua orang tuanya untuk ikut bertempur melawan penjajah. Namun kedua orangtuanya tidak mengizinkannya. Ia kemudian memilih hanya menjadi anggota Masyumi dan aktif dalam kegiatan politik. Aktivitas politiknya ini kemudian mengantarkannya menjadi anggota Dewan Wakil Rakyat di Blora mewakili Masyumi setelah ia berhasil menyelesaikan pendidikannya pada tahun $1946 .{ }^{7}$

(ketiganya pada tahun 1977). Sementara PLPA sejak tahun 1976/1977 hingga tahun 1990-an telah berlangsung 13 angkatan dan telah menghasilkan 296 alumni dari seluruh Indonesia. Peserta PLPA terdiri atas para peneliti di lingkungan Badan Litbang Agama, IAIN, perguruan tinggi dan lembaga-lembaga penelitian yang lain. Untuk informasi singkat tentang SPS lihat Waryani Fajar Riyanto, Studi Islam Indonesia (1950-2014) (Yogyakarta: Kurnia Kalam Semesta, 2014), 266-272; sedang PLPA lihat Sudjangi (ed.), Kajian Agama dan Masyarakat 15 Tahun Badan Penelitian dan Pengembangan Agama, 1975-1990 (Jakarta: Departemen Agama RI, 1992), $\mathrm{x}$.

${ }^{4}$ A. Singgih Basuki yang meneliti pemikiran keagamaan A. Mukti Ali menyatakan bahwa paling tidak ada tiga jenis metodologi yang dikemukakan oleh A. Mukti Ali, yaitu metodologi studi Islam, agama, dan perbandingan agama. Dalam penelitiannya, Singgih membedakan ketiga pemikiran metodologi itu dan membahasnya secara berbeda. Lihat Basuki, Pemikiran Keagamaan A. Mukti Ali, 91-111.

${ }^{5}$ Ali Munhanif, "Prof. Dr. A. Mukti Ali; Modernisasi Politik-Keagamaan Orde Baru” dalam Azyumardi Azra dan Saiful Umam (ed.), Menteri-menteri Agama RI Biografi Sosial Politik(Jakarta: INIS, PPIM dan Balitbang Depag RI, 1998 ), 273 dan 275.

${ }^{6}$ Munhanif, "Prof. Dr. A. Mukti Ali", 273-274.

${ }^{7}$ Munhanif, "Prof. Dr. A. Mukti Ali", 276-278. 
Selain gagal menjadi tentara, Mukti Ali juga gagal menjadi pengikut tarikat. Meski sempat mengamalkan tarikat Naqsyabandiyah, sang pemimpin tarikat, KH. Hamid Dimyati (gurunya di Pesantren Termas) menganjurkannya untuk berhenti mengamalkan tarikat ini. Sang guru melihat Mukti Ali tidak berbakat menjadi mutasawwif. Sang guru juga tidak mengizinkannya mengkaji kitab Hikam, malah menganjurkannya untuk mempelajari kitab Mihakek al-Nazhar yang berisi teori tentang analisis dari filsafat logika al-Ghazali. Dia mengikuti saran sang guru. ${ }^{8}$

Pada tahun 1947, Mukti Ali melanjutkan pendidikannya di STI (Sekola Tinggi Islam) di Yogyakarta. Di sinilah ia bertemu dengan KH. Mas Mansur, dosen STI sekaligus tokoh Muhammadiyah. Kekagumannya pada dosennya ini mendorongnya untuk dekat dan aktif di Muhammadiyah. Pada tahun 1949 studinya di STI terhenti karena agresi Belanda ke Yogyakarta. Pada peristiwa ini, ia bergabung dengan Angkatan Perang Sabil (APS) bertempur melawan Belanda. Selanjutnya, tahun 1950 ia berangkat ke Mekkah untuk naik haji dan belajar di sana. Setelah hampir setahun belajar di Mekkah, atas nasihat Imron Rosyadi (Konsul Haji Indonesia saat itu), ia memutuskan untuk belajar ke negara lain, pilihannya jatuh pada Pakistan. Di Pakistan ia menempuh studi di Universitas Karachi pada Fakultas Sastra Arab tingkat sarjana muda dan kemudian diteruskan ke tingkat Ph.D di universitas yang sama hingga selesai. ${ }^{9}$

Tahun 1955, ketika akan pulang ke Indonesia, ia menerima kabar bahwa ia tidak diperkenankan pulang oleh Sekjen Masyumi, Anwar Harjono, karena ia diminta untuk meneruskan studinya ke Kanada dan namanya sudah terdaftar di Institute of Islamic Studies, McGill University, Montreal Kanada dengan spesialisasi Ilmu Perbandingan Agama. Di sinilah ia mengenal metode studi agama-agama dan dekat dengan sejumlah profesor kajian Islam terutama Wilfred Cantwell Smith yang sangat dikaguminya. Pada Tahun 1957 ia berhasil menamatkan pendidikannya di McGill dan memperoleh gelar Master of Arts dengan tesis yang berjudul Bibliographical Study of Mubammadiyah Movement. Pada tahun ini juga ia kembali ke Indonesia. ${ }^{10}$

Setelah tiba di Indonesia, Mukti Ali sempat menjadi tenaga administrasi di Departemen Agama selama dua atau tiga bulan. Ia kemudian mengajar di Akademi Dinas Ilmu Agama (ADIA) Jakarta dan PTAIN Yogyakarta sejak tahun 1957. Tahun 1960 ia memimpin Jurusan Perbandingan Agama di Yogyakarta dan menetap di sana sejak tahun 1963. Ketika menetap di sana, rumahnya dijadikan tempat berkumpul sekelompok anak muda dari HMI dalam sebuah perkumpulan yang bernama limited group (1967-1971). ${ }^{11}$ Kelompok ini mendiskusikan berbagai masalah keagamaan terutama isuisu pembaruan. Tahun 1964 ia menjabat Rektor III dan 1968 menjabat rektor I. Tahun 1971 ia dikukuhkan sebagai guru besar ilmu agama di IAIN Sunan Kalijaga dan pada tahun ini juga ia diangkat menjadi menteri agama dan pindah ke Jakarta. ${ }^{12}$

Mukti Ali menjabat menteri agama selama dua periode (1971-1978, dilantik pertama kali tanggal 11 September 1971). Selama dua periode jabatannya itu ada delapan masalah yang menjadi perhatiannya. Pertama, masalah konsep pembangunan. Ia merumuskan konsep "pembangunan manusia Indonesia seutuhnya dan masyarakat Indonesia seluruhnya". Kedua, masalah kerukunan hidup beragama. Untuk mengatasi ketegangan antaragama, Mukti Ali melancarkan dialog antarumat

\footnotetext{
${ }^{8}$ Munhanif, "Prof. Dr. A. Mukti Ali”, 275-276.

${ }^{9}$ Munhanif, "Prof. Dr. A. Mukti Ali", 278-281.

${ }^{10}$ Munhanif, "Prof. Dr. A. Mukti Ali”, 281-284.

${ }^{11}$ Untuk paparan singkat tentang Limited Group lihat: Basuki, Pemikiran Keagamaan A. Mukti Ali, 22 dan 73-77.

${ }^{12}$ Bagaimana proses Mukti Ali menjadi menteri agama dan faktor-faktor politik di belakangnya dapat dibaca pada:
} Munhanif, "Prof. Dr. A. Mukti Ali”, 284-292. 
beragama di kalangan para ahli agama berlatar belakang akademisi dan menumbuhkan inisiatif dialog dari bawah (umat) bukan dari atas (pemerintah). Masalah-masalah yang didialogkan lebih diarahkan dan ditekankan pada pembangunan agama bukan pada masalah-masalah teologis. Ketiga, masalah bentuk negara yang saat itu masih menjadi problem di kalangan umat Islam. Rumusan kompromis yang ditawarkan oleh Mukti Ali adalah Indonesia merupakan negara Pancasila, bukan negara sekuler dan bukan pula negara teokratis. Keempat, masalah intern umat Islam terkait bidang pendidikan. Mukti Ali terlibat dalam proses munculnya SKB Tiga Menteri yang melahirkan perubahan kurikulum pada madrasah yang asalnya 70\% agama 30\% umum menjadi terbalik 70\% umum 30\% agama. Adanya SKB ini memungkinkan lulusan madrasah dapat meneruskan ke sekolah dan perguruan tinggi umum. Kelima, masalah IAIN terutama terkait mutu tenaga pengajar dan pengembangan tradisi ilmiah. Kebijakan Mukti Ali mengenai masalah ini adalah dengan menyelenggarakan Post Graduate Course (PGC), menyelenggarakan Studi Purna Sarjana (SPS) yang kemudian menjadi embrio lahirnya pascasarjana di IAIN dan mengirim dosen-dosen IAIN belajar ke luar negeri. Keenam, masalah tidak adanya wadah yang mnghimpun umat Islam dalam suatu organisasi yang akan menjadi penghubung antara umat dan pemerintah. Mukti Ali melihat perlunya menghimpun seluruh ulama yang mewakili umat Islam seluruh Indonesia. Karena itu, ia terlibat dan ikut mendorong terbentuknya MUI (Majelis Ulama Indonesia) pada tahun 1975. Ketujuh, penyelesaian masalah Rancangan Undang-Undang Perkawinan yang sempat menjadi polemik. Kedelapan, masalah sumber daya pesantren. Mukti Ali melihat perlunya para santri diberikan bekal keterampilan agar tidak canggung untuk ikut terlibat dalam menggerakkan roda pembangunan terutama di desa. Untuk itu diadakanlah pelatihan keterampilan bagi para santri seperti pertanian, perikanan, tambak, pertukangan dan lain sebagainya. ${ }^{13}$

Pada tahun 1978 Mukti Ali tidak lagi duduk di kabinet. Meski demikian, pemerintah Orde Baru masih menempatkannya menjadi anggota DPA (Dewan Pertimbangan Agung) untuk periode 1978-1983 yang saat itu diketuai oleh K.H. Idham Chalid. Saat menjadi anggota DPA, ia lebih memilih beraktivitas di Yogyakarta dan aktif kembali mengajar di IAIN Sunan Kalijaga. ${ }^{14}$

Setelah aktif di IAIN Sunan Kalijaga, Mukti Ali mengajar di Jurusan Perbandingan Agama Fakultas Ushuluddin. Pada tahun 1988, setelah pensiun, ia mengundurkan diri dari Fakultas Ushuluddin dan berkonsentrasi hanya mengajar di program pascasarjana IAIN Sunan Kalijaga yang telah dibuka sejak tahun 1983/1984. Perhatiannya yang besar untuk meningkatkan mutu dosen, ia kemudian mengusulkan diadakan Diskusi Ilmiah Dosen-dosen Tetap IAIN Sunan Kalijaga setiap Jumat sore. Kegiatan ini ternyata kemudian berlangsung selama beberapa dekade sejak diadakan pada tahun 1978. ${ }^{15}$

Di samping mengajar dan menulis, aktivitas lain Mukti Ali setelah tidak lagi menjadi menteri, di antaranya adalah menjadi anggota Dewan Riset Nasional pada tahun 1984. Pada tahun 1992, ia ditarik menjadi anggota AIPI (Akademi Ilmu Pengetahuan Indonesia). Ia juga menjadi dewan penyantun di beberapa universitas, seperti UGM, UMY dan ISI dan pada tahun 1993-1998 ia menjadi anggota Majelis Permusyawaratan Rakyat (MPR). ${ }^{16}$

${ }^{13}$ Muhammad Damami dkk, “H.A Mukti Ali: Ketaatan, Kesalehan dan Kecendikiaan” dalam Djam'annuri, 70 Tahun H.A. Mukti Ali: Agama dan Pembangunan (Yogyakarta: IAIN Sunan Kalijaga, Press), 34-39; Lihat pula Muhammad Damami, dkk., "Prof. Dr. H. A. Mukti Ali, M.A." dalam Lima Tokoh IAIN Sunan Kalijaga Yogyakarta (Yogyakarta: Suka Press, 2000), $259-265$.

${ }^{14}$ Damami dkk, "H.A Mukti Ali: Ketaatan, Kesalehan dan Kecendekiaan, 39-40; Lihat pula Damami, dkk., "Prof. Dr. H. A. Mukti Ali, M.A.”, 266.

${ }^{15}$ Damami dkk, "H.A Mukti Ali: Ketaatan, Kesalehan dan Kecendekiaan, 40; Lihat pula Damami, dkk., "Prof. Dr. H. A. Mukti Ali, M.A.”, 266.

${ }^{16}$ Damami dkk, "H.A Mukti Ali: Ketaatan, Kesalehan dan Kecendekiaan, 42-43; Lihat pula Damami, dkk., "Prof. Dr. H. A. Mukti Ali, M.A.”, 269. 
Mukti Ali meninggal dunia pada tanggal 5 Mei 2004 dalam usia mendekati 81 tahun sekitar pukul 17.30 di Rumah Sakit Umum Dr. Sardjito Yogyakarta. Jenazahnya dimakamkan di pemakaman keluarga besar IAIN Sunan Kalijaga di Desa Kadisoko, Kecamatan Kalasan, Kabupaten Sleman. ${ }^{17}$

Selama karirnya sebagai intelektual dan birokrat, Mukti Ali telah menghasilkan banyak tulisan baik sebelum maupun sesudah menjadi menteri agama. Beberapa karya intelektualnya sejak dekade 60-an hingga dekade 90-an di antaranya adalah (1) Pemberontakan Abmad Urabi dan Perjuangan Konstitusi di Mesir, (2) Gerakan Imam Mabdi di Sudan, (3) Alam Pikiran Modern di Indonesia dan Modern Islamic Thought in Indonesia, (4) Perbagai Persoalan Islam di Indonesia, (5) An Introduction to Government of Atjeb Sultanate, (6) Ilmu Perbandingan Agama (Sebuah Pembahasan tentang Methodos dan Sistima), (7) Keesaan Tuhan dalam Al-Qur'an, (8) Asal usul Agama, (9) Etika Agama dalam Pembinaan Kepribadian Nasional dan Pemberantasan Kemaksiatan dari Segi Agama Islam, (10) Bagaimana Menghampiri Isra'dan Miraj Nabi Besar Muhammad S.A.W. atau Iman dan Imu Pengetahuan, (11) Kuliah Agama di SESKAU Lembang, (12) Masalah Kegiatan Ilmu Pengetahuan dalam Rangka Pembangunan Nasional (Dengan Kelompok Agama), (13) Dialog Antar Agama, (14) Beberapa Masalah Pendidikan di Indonesia, (15) Ibnu Chaldun dan Asal Ushul Sosiologi, (16) Faktor-faktor Penyiaran Islam di Indonesia, (17) Seni, Ilmu dan Agama, (18) Religion and Development in Indonesia, (19) Laboratorium Hisab dan Ru'yah, (20) Agama dan Pembangunan di Indonesia, (21) Beberapa Persoalan Agama Dewasa Ini, (22) Ilmu Perbandingan Agama di Indonesia, (23) Muslim Bilali dan Muslim Mubajir di Amerika Serikat, (24) Ijtihad dalam Pandangan Muhammad Abduh, Abmad Dablan dan Muhammad Iqbal, (25) Ta’lim al-Muta'allim Versi Imam Zarkasyi Suatu Pembahasan Perbandingan tentang Metodologi Pendidikan Agama di Abad Pertengahan dan di Pondok Modern Darussalam Gontor Ponorogo, (26) Metode Mehamami Agama Islam, (27) Memahami Beberapa Aspek Ajaran Islam, (28) Alam Pikiran Islam Modern di India dan Pakistan, (29) Himpunan Esai tentang Beberapa Aspek Islam, (30) Islam dan Sekulerisme di Turki Modern, dan (31) Alam Pikiran Modern di Timur Tengah.

Tulisan-tulisan Mukti Ali selain dalam bentuk karya yang utuh, ada juga yang dimuat dalam sejumlah buku yang merupakan kumpulan tulisan yang berasal dari sejumlah tokoh intelektual. Tulisan Mukti Ali misalnya dimuat pada buku Penelitian Agama Masalah dan Pemikiran (ed. Mulyanto Sumardi), Kajian Agama dan Masyarakat: 15 Tabun Badan Penelitian dan Pengembangan Agama, 1975-1990,(ed. Sudjangi), Metodologi Penelitian Agama Sebuab Pengantar (ed. Taufik Abdullah dan Rusli Karim), Imu Perbandingan Agama di Indonesia (Beberapa Permasalaban) (Tim Redaksi: Zaini Muchtarom dkk.), Ilmu Perbandingan Agama di Indonesia dan Belanda (redaktur: Burhanuddin Daya dan Herman Leonard Beck) dan masih banyak lagi.

Dari sekian banyak karya Mukti Ali di atas, A. Singgih Basuki, yang meneliti pemikiran keagamaannya, menyimpulkan bahwa pemikiran Mukti Ali sebagaimana yang tercantum dalam sejumlah karyanya itu dibangun atas tiga etos, yaitu keilmuan, kemanusiaan, dan kebangsaan. Etos keilmuannya dikenal dengan pendekatan scientific-cum-doctrinaire, pendekatan yang memadukan aspek doktrin dan ilmiah. Etos kemanusiaannya dikenal dengan ungkapannya: "pembangunan manusia seutuhnya", dan etos kebangsaannya dikenal dengan konsep atau semboyan agree in disagreement serta dialog antaragama untuk menciptakan kerukunan intern dan antarumat beragama dalam berbangsa. ${ }^{18}$ Perlu pula dilihat bahwa ia juga memiliki perhatian besar pada ide-ide pembaruan kaum modernis. Sejumlah karya intelektualnya seperti Alam Pikiran Islam Modern di India dan Pakistan, Islam dan Sekulerisme

${ }^{17}$ Budi Handrianto, 50 Tokoh Islam Liberal Indonesia Pengusung Ide Sekularisme, Pluralisme dan Liberalisme Agama (Jakarta: Hujjah Press, 2007), 15; Lihat pula Basuki, Pemikiran Keagamaan A. Mukti Ali, 15.

${ }^{18}$ Basuki, Pemikiran Keagamaan A. Mukti Ali, 273-274. 
di Turki Modern, dan Alam Pikiran Modern di Timur Tengah menunjukkan pentingnya gagasan modernisme Islam.

\section{Aspek Metodologis Penelitian Agama Perspektif A. Mukti Ali}

Untuk menguraikan pemikiran metodologis Mukti Ali, di sini akan dikemukakan lima tulisan Mukti Ali yang dipublikasikan dalam rentang waktu yang berbeda, yaitu Ilmu Perbandingan Agama: Sebuah Pembahasan tentang Metodos dan Sistema (1964), "Penelitian Agama di Indonesia" (dimuat dalam Mulyanto Sumardi [ed.], Penelitian Agama Masalah dan Pemikiran) (1982), Ilmu Perbandingan Agama di Indonesia (1988), "Metodologi Ilmu Agama Islam" (dimuat dalam Taufik Abdullah dan M. Rusli Karim [eds.], Metodologi Penelitian Agama Sebuab Pengantar) (1989) dan "Penelitian Agama (Suatu Pembahasan tentang Metode dan Sistem) dimuat dalam A. Makmur Makka (ed.), 70 Tabun B.J. Habibie (1996). Pemikiran metodologis A. Mukti Ali yang terdapat dalam sejumlah tulisannya ini disajikan dalam tiga tema berikut ini.

\section{Penggunaan Metode Ilmiah dan Ilmu-ilmu Sosial dalam Penelitian Agama}

Mukti Ali memperkenalkan penggunaan metode ilmiah dalam penelitian agama pada dekade 60-an. Orasi ilmiah yang disampaikannya pada tahun 1964 yang berjudul Ilmu Perbandingan Agama (Sebuah Pembahasan tentang Methodos dan Sistima) meski dalam konteks Ilmu Perbandingan Agama merupakan fase awal gagasannya mengenai pentingnya metode ilmiah dalam penelitian agama. Dalam buku ini Mukti Ali mengenalkan beberapa metode atau pendekatan dalam mengkaji agama secara ilmiah. Dalam bahasannya mengenai Ilmu Perbandingan Agama ini, ia menarik pembedaan antara pendekatan apologis dan pendekatan ilmiah. Menurutnya, kajian perbandingan agama bukanlah apologi dan bukan pula suatu alat untuk mempertahankan kepercayaan dan agama seseorang, tetapi perbandingan agama adalah alat untuk memahami fungsi dan ciri agama. ${ }^{19}$

Perbandingan agama, menurut Mukti Ali, harus ditempatkan dalam hubungannya dengan cabang Ilmu Agama (Science of Religions) ${ }^{20}$ lainnya. Ia memperkenalkan tiga cabang Ilmu Agama. Pertama, Sejarah Agama (bistory of religion), yaitu ilmu yang yang mempelajari fakta-fakta asasi agama dan berusaha menilai data historis untuk mendapatkan gambaran dan pemahaman yang jelas tentang pengalaman keagamaan. Untuk memahami perkembangan agama, Sejarah Agama menggunakan ilmu bantu lainnya seperti Antropologi, Sosiologi, Psikologi, Arkeologi dan lainnya. Kedua, Perbandingan

${ }^{19}$ A. Mukti Ali, Ilmu Perbandingan Agama (Sebuah Pembahasan Methodos dan Sistima) (Yogyakarta: Yayasan "Nida", 1975), Cet. Ke-4, 7.

${ }^{20} \mathrm{Ilmu}$ agama di Barat memiliki banyak nama, di antaranya adalah (Allgemeine) Religionswissenschaft, Science of Religions, The History of Religions, Comparative Studies of Religions, Phenomenology of Religion, The Study of World Religions. Lihat M. Sastrapratedja, "Peran Ilmu Perbandingan Agama" dalam Tim Redaksi INIS, Ilmu Perbandingan Agama di Indonesia (beberapa Permasalahan), Seri INIS Jilid VII (Jakarta: INIS, 1990), 57. Mukti Ali sendiri di samping menggunakan Ilmu Perbandingan Agama dalam buku dan makalah yang ditulisnya, ia juga menggunakan istilah Religionswissenschaft (Ilmu Agama) dalam tulisannya. Ali menyebutkan beberapa nama yang sepadan dengan Ilmu Perbandingan Agama, yaitu Ilmu Agama, Sejarah Agama, atau Fenomenologi Agama. Lihat misalnya pada A. Mukti Ali, Ilmu Perbandingan Agama di Indonesia (Bandung: Mizan, 1995), 70-74. Istilah lain belakangan yang juga mulai populer digunakan adalah Religious Studies (Studi Agama). Berbeda dengan Mukti Ali, Farichin Chumaidi memiliki pandangan yang berbeda. Baginya, Ilmu Perbandingan Agama bukanlah nama lain dari Ilmu Agama maupun Fenomenologi Agama. Ilmu Perbandingan Agama adalah cabang atau salah satu ilmu bantu dari Ilmu Agama sebagaimana Sosiologi Agama, Sejarah Agama, Fenomenologi Agama, dan lainnya. Dalam hal ini ia tidak sejalan dengan Mukti Ali yang cenderung mengidentikkan Ilmu Perbandingan Agama dengan Ilmu Agama atau sejarah agama. Lihat H.A. Farichin Chumaidy, "Ilmu Perbandingan Agama dan Hubungannya dengan Sosiologi Agama dan Sejarah Agama" dalam Burhanuddin Daya dan Herman Leonard Beck (ed), Ilmu Perbandingan Agama di Indonesia dan Belanda, (Jakarta: INIS, 1992), 26. 
Agama, yaitu ilmu yang berusaha memahami temuan sejarah agama dengan cara membandingkan agama-agama untuk menemukan struktur fundamental pengalaman-pengalaman keagamaan dan berbagai konsep keagamaan melalui analisis persamaan dan perbedaannya. Ketiga, filsafat agama, yaitu cabang ilmu agama yang berusaha menarik kesimpulan dari fakta-fakta yang dikumpulkan oleh Sejarah Agama dan dibandingkan oleh Perbandingan Agama dalam arena falsafi. ${ }^{21}$

Penjelasan Mukti Ali di atas menunjukkan adanya relasi dan ketergantungan beberapa cabang Ilmu Agama dalam memahami agama. Perbandingan Agama bergantung dari informasi yang ditemukan oleh sejarah agama. Informasi dari Sejarah Agama menjadi bahan perbandingan untuk dilihat persamaan dan perbedaan aspek-aspek tertentu dari sejumlah agama. Hasil dari sejarah agama dan perbandingan agama kemudian menjadi bahan penting bagi filsafat agama untuk melakukan pemaknaan secara filosofis terhadap fakta-fakta keagamaan itu. ${ }^{22}$

Selain memperkenalkan secara singkat ketiga cabang Ilmu Agama di atas, Mukti Ali juga mengemukakan beberapa metode mempelajari dan meneliti agama. Beberapa metode (methodos) itu adalah metode Filologi, metode Antropologi, metode Sosiologi, dan metode historis. ${ }^{23}$ Setelah memperkenalkan adanya penggunaan metode ilmiah dalam studi agama, Mukti Ali menekankan pentingnya kerjasama antara Ilmu Perbandingan Agama dan ilmu-ilmu sosial untuk memahami dan menafsirkan fenonema agama. Ia menyatakan bahwa untuk mendapatkan materi, alat-alat penelitian, dan perbaikan metode Ilmu Perbandingan Agama banyak tergantung pada ilmu-ilmu lain, seperti Prasejarah, Sejarah, Arkeologi, Geografi, Antropologi Fisik, Etnologi, Psikologi, Filologi, Sosiologi, Psikologi Sosial, Kritik Kitab Suci dan pengetahuan lainnya termasuk ekonomi, hukum dan lembaga politik. ${ }^{24}$ Menurutnya, seiring dengan semakin berkembangnya teori dan metode disiplin ilmu sosial perlu ada sintesa perbagai ilmu pengetahuan yang saling berhubungan dalam menginterpretasikan agama. $^{25}$

Kesulitan penggunaan metode ilmiah dalam studi agama menurut Mukti Ali adalah bagaimana harus bersikap objektif dalam mengkaji agama tanpa berat sebelah. Kesulitan lainnya adalah perbedaan konsep yang digunakan seseorang dalam mendekati agama yang berdampak pada perbedaan hasil yang dicapai. ${ }^{26}$ Mukti Ali melihat kesulitan yang sama juga dialami oleh umat Islam di Indonesia. Karena menurut penilaiannya, studi agama-agama yang dilakukan (pada dekade 60-an) masih menggunakan pendekatan apologis dan polemis, bukan pendekatan ilmiah yang objektif.

Pada dekade 60-an, pemikiran Mukti Ali tentang perlunya metode ilmiah dan penggunaan ilmu-ilmu sosial dalam mengkaji agama masih dianggap asing oleh umat Islam. Karena itu ia berusaha meyakinkan pembaca muslim tentang kemungkinan penggunaan Ilmu Perbandingan Agama dengan metode ilmiahnya dalam mengkaji agama tanpa mengorbankan kebenaran Islam. Ia bahkan meyakinkan bahwa dengan mempelajari agama-agama lain umat Islam (muballigh dan ahli Islam) justru akan menemukan finalitas dan kesempurnaan Alquran dan Islam. Umat Islam akan menemukan letak kelebihan-kelebihan Islam dibanding agama-agama lain yang pada gilirannya akan meningkatkan keyakinan terhadap ajaran-ajaran Islam. Tetapi ia juga mengingatkan bahwa Ilmu Perbandingan Agama

${ }^{21}$ Mukti Ali, Ilmu Perbandingan Agama, 5-7.

${ }^{22}$ Rahmadi, dkk.,Dinamika Pemikiran Sarjana Muslim tentang Metodologi Studi Agama di Indonesia: Kajian terhadap LiteraturTerpublikasi Tahun 1964-2012 (Banjarmasin: IAIN Antasari Press, 2014), 54.

${ }^{23}$ Rahmadi, dkk., Dinamika Pemikiran Sarjana Muslim, 54.

${ }^{24}$ Ali, Ilmu Perbandingan, 10-11.

${ }^{25}$ Ali, Ilmu Perbandingan, 10.

${ }^{26}$ Ali, Ilmu Perbandingan, 10. 
juga mengandung bahaya bagi Islam jika salah menggunakannya. Tetapi sebaliknya, jika ilmu ini dipergunakan dengan benar, ilmu ini justru akan sangat membantu perkembangan Islam karena perluasan Islam akan lebih kuat dari sebelumnya. ${ }^{27}$ Ia juga berusaha meyakinkan kalangan muslim agar tidak lagi hanya berkutat pada cara apologis dan polemis dalam membela Islam, tetapi juga beralih untuk menggunakan pendekatan ilmiah dalam memahami agama-agama terutama Islam sendiri. Cara ini tidak hanya memperdalam keyakinan terhadap Islam tetapi juga menimbulkan sikap saling menghargai terhadap agama-agama lain. Ia menyarankan agar umat Islam mengenyampingkan prasangka-prasangka yang bukan-bukan terhadap agama lain agar penyelidikan ilmiah dapat dilakukan oleh umat Islam. ${ }^{28}$

Pemikiran Mukti Ali di atas merupakan tahap awal gagasan metodologisnya yang ditujukan kepada para pembaca muslim pada dekade 60-an di mana ketika pemikiran itu disampaikan, sebagaimana telah disebut sebelumnya, mereka masih asing dengan penggunaan metode ilmiah dan ilmu-ilmu sosial dalam mengkaji agama-agama. Kondisi ini "memaksa" Mukti Ali sendiri menggunakan apologi juga untuk meyakinkan muslim agar beralih dari model kajian apologis-polemis ke kajian ilmiah.

Beberapa paparan di atas menunjukkan bahwa penelitian agama, dalam konteks dan perspektif Ilmu Perbandingan Agama, harus dilakukan dengan beberapa acuan berikut. Pertama, penelitian agama dilakukan dengan menggunakan metode ilmiah dan dilakukan secara objektif (tidak berat sebelah). Kedua, penelitian agama yang ilmiah menuntut tidak digunakannya pendekatan apologis-polemis dalam mengkaji agama. Ketiga, penelitian agama sebaiknya menggunakan metode-metode ilmu sosialhumaniora dengan cara melakukan sintesa berbagai ilmu pengetahuan dalam menafsirkan agama.

\section{Penelitian Agama: Objek, Peneliti, Tahapan, Tipe dan Metode}

Dalam tulisannya yang berjudul "Penelitian Agama (Suatu Pembahasan tentang Metode dan Sistem)" Mukti Ali menyatakan bahwa objek penelitian agama adalah tindak laku umat beragama, yaitu sejauhmana ajaran agama diwujudkan dalam hubungan antara sesama manusia dalam hidup kemasyarakatan. Dengan demikian ada hubungan dan pengaruh timbal balik antara perkembangan agama dan masyarakat yang harus menjadi sasaran penelitian yang harus menjadi sasaran penelitian agama. $^{29}$

Bidang yang digarap oleh penelitian agama, menurut Mukti Ali ada empat, yaitu (1) lembaga agama, yaitu badan yang berfungsi melakukan tugas agama, (2) hubungan agama, meliputi hubungan antara individu atau kelompok intern agama sendiri atau antar berbagai agama, (3) fungsi agama, yaitu sejauhmana agama mempengaruhi hidup dan kehidupan individu atau masyarakat, dan (4) teks agama (bahan-bahan tertulis tentang agama) dan dokumen agama (segala sesuatu baik tulisan, foto, patung, gedung dan sebagainya yang bisa memberikan informasi tentang agama). ${ }^{30}$

Di tempat lain, Mukti Ali menyebutkan bahwa penelitian agama dalam konteks perbandingan agama adalah pengalaman agama. Pengalaman agama diekspresikan dalam tiga bentuk. Bentuk pertama adalah ekspresi teoretis atau intelektualitas (termasuk di dalamnya teologi, kosmologi dan antropologi). Bentuk kedua adalah ekspresi praktis atau amalan (ibadah). Bentuk ketiga adalah ekspresi

${ }^{27}$ Ali, Ilmu Perbandingan, 38-39.

${ }^{28}$ Ali, Ilmu Perbandingan, 40-41. Lihat juga Rahmadi, dkk., Dinamika Pemikiran Sarjana Muslim, 55-56.

${ }^{29}$ A. Mukti Ali, "Penelitian Agama (Suatu Pembahasan tentang Metode dan Sistem)" dalam A. Makmur Makka (ed.), 70 Tahun B.J. Habibie (Jakarta: Pustaka CIDESINDO, 1996), 33.

${ }^{30}$ Ali, "Penelitian Agama (Suatu Pembahasan tentang Metode dan Sistem)", 34. 
sosiologis, yaitu ekspresi dalam pergaulan. ${ }^{31}$

Objek material penelitian agama sebagaimana disebut di atas, menurut Mukti Ali sering kali memiliki kesamaan dengan objek material kajian ilmu-ilmu sosial, yakni hubungan antara manusia dan masyarakat. Akibat kesamaan objek ini, tidak jarang antara ilmu agama dan ilmu-ilmu sosial mengkaji objek yang sama dengan metode dan pendekatannya masing-masing. Mungkinkah ilmu agama dan ilmu-ilmu sosial saling bekerjasama dalam menggarap fenomena keagamaan yang menjadi objek penelitian agama?Kalau mungkin bagaimana bentuknya? Di bawah ini akan dipaparkan pemikiran Mukti Ali mengenai masalah tersebut.

Dalam tulisannya yang berjudul "Penelitian Agama di Indonesia", Mukti Ali memaparkan adanya kecenderungan di kalangan ahli sosial dan ahli agama untuk saling mendekat dan menjalin kerjasama dalam meneliti fenomena keagamaan. Di kalangan ahli ilmu sosial muncul kecenderungan untuk meneliti masalah agama dan sebaliknya di kalangan ahli ilmu agama muncul kecenderungan untuk meneliti agama dengan menggunakan ilmu dan metodologi ilmu sosial. Kecenderungan ini, menurutnya, merupakan sesuatu yang positif untuk menutupi masing-masing kekurangan. Kalangan ahli ilmu sosial merasa tidak cukup hanya mengkaji dan memahami fenomena keagamaan hanya berdasarkan perspektif ilmu sosial saja tanpa melibatkan perspektif agama. Sebaliknya, di kalangan ahli ilmu agama juga muncul kesadaran bahwa mengkaji fenomena keagamaan tidak cukup hanya menggunakan spekulasi teoritis atau menggunakan metode deduktif, tetapi diperlukan juga metode empiris dan induktif dalam memahami agama sebagaimana yang dilakukan dalam ilmu sosial. ${ }^{32}$

Jika situasi konkret pengalaman keagamaan sama-sama menjadi sasaran penelitian ahli ilmu agama dan ahli ilmu sosial, menurut Ali, akan memunculkan pertanyaan apakah penelitian agama akan meminjam hasil-hasil pengamatan dan penelitian ilmu-ilmu sosial? Ataukah penelitian agama seharusnya mempunyai alat-alatnya sendiri untuk menghadapi dan dan meneliti situasi konkret itu? Pertanyaan lainnya adalah dapatkah kenyataan sosial dihadapi dan diteliti secara agamaniah? ${ }^{33}$

Menurut Ali, penelitian agama bersangkut paut dengan refleksi agamaniah atas pengalaman umat dalam situasi konkret dengan sikap agamaniah. Refleksi agamaniah adalah refleksi agama itu sendiri dan refleksi dalam agama. Dalam hal ini perlu dipahami tentang ajaran agama itu sendiri dan bagaimana manifestasi agama itu dalam kehidupan masyarakat. Meneliti masyarakat beragama berarti meneliti gejala-gejala yang erat hubungannya dengan gejala-gejala masyarakat beragama. Cara mengkaji gejala-gejala tersebut mirip dengan cara pengumpulan data dalam Sosiologi. Tetapi pengumpulan data itu bukanlah Sosiologi melulu, karena umat beragama menafsirkan gejala-gejala dalam masyarakat itu dalam cahaya ajaran agamanya. Jadi penelitian agama tidak hanya memaparkan data tetapi sekaligus menafsirkannya. ${ }^{34}$

Penelitian sosial terhadap agama, menurut Mukti Ali, hanya mendeskripsikan realitas-konkret fenomena keagamaan. Di dalamnya tidak mengandung refleksi atau tanggapan agamis yang seharusnya ditempatkan dalam keseluruhan proses penelitian. Untuk itu diperlukan kerjasama antara ilmu sosial

\footnotetext{
${ }^{31}$ Ali, Ilmu Perbandingan Agama di Indonesia, 79-70.

${ }^{32}$ A. Mukti Ali, "Penelitian Agama di Indonesia", dalam Mulyanto Sumardi (ed.), Penelitian Agama Masalah dan Pemikiran, (Jakarta: Sinar Harapan, 1982), 20-21; Lihat juga Ali, "Penelitian Agama (Suatu Pembahasan tentang Metode dan Sistem)", $26-27$.

${ }^{33} \mathrm{Ali}$, "Penelitian Agama di Indonesia", 23-24. Terkait tentang apa yang dimaksud dengan refleksi agamis (agamaniah), Ali menjelaskan bahwa refleksi agamis adalah refleksi atas iman sendiri dan refleksi dalam iman. Beriman adalah berkeyakinan yang diikuti dengan perbuatan yang sesuai dengan keyakinannya itu.Iman adalah keyakinan atau kepercayaan yang membuahkan perbuatan. Hidup beriman tidak hanya terkait masalah batiniah saja atau pribadi saja, ia menyangkut keseluruhan hidup, baik pribadi maupun masyarakat. Ali, "Penelitian Agama (Suatu Pembahasan tentang Metode dan Sistem)”, 29.

${ }^{34} \mathrm{Ali}$, "Penelitian Agama di Indonesia", 25.
} 
dan ilmu agama. Ilmu sosial menyediakan bahan bagi agama, sedang agama akan melakukan refleksi agamis dengan cara mencari makna dan menafsirkan data dan gejala itu dalam cahaya agama. ${ }^{35}$

Aspek penting berikutnya yang mendapat penekanan dari Mukti Ali adalah faktor peneliti. Baginya, faktor peneliti lebih memiliki peran penting dalam penelitian dibanding metode penelitian. Metode penelitian memang merupakan satu aspek penting yang tidak bisa ditinggalkan dalam penelitian. Tetapi aspek metode bukan merupakan jaminan bahwa penelitian itu tepat.Metode hanyalah alat. Baginya faktor peneliti merupakan kunci penting penelitian. Faktor-faktor kedalaman pemahaman dalam memahami masalah-masalah sosial dan agama, integritas pribadi, sensitif dalam persepsi, disiplin dalam imajinasi, dan reserve dalam mental jelas mengarah pada arti penting dari seorang peneliti. Karena itu, membahas penelitian tidak hanya berbicara masalah strategi dan teknik penelitian tetapi juga faktor pribadi ilmiah peneliti. ${ }^{36}$

Faktor peneliti juga menjadi penting karena ia berkaitan dengan aspek interpretasi terhadap fakta-fakta sosial yang sedikit banyaknya dipengaruhi oleh latar belakang si peneliti. Menurutnya, interpretasi terhadap fakta sosial banyak mengandung interpretasi. Interpretasi itu tergantung pada pertanyaan peneliti dan latar belakang peneliti. Mukti Ali tidak sepakat bahwa fenomena agama dapat dipahami atau diinterpretasikan dengan baik oleh peneliti yang tidak memiliki latar belakang sebagai orang beragama. Dalam hal ini Mukti Ali menulis:

Dalam hubungan ini kami ingin menekankan suatu unsur hingga dengan demikian seluruh pendekatan empiris diwarnainya, yakni sikap peneliti agama.Agama pada manusia adalah begitu pribadi dan dalam sehingga hanya dapat diamati dengan berhati-hati. Seorang peneliti yang secara teknis mungkin sangat baik belum pasti dapat menemukan persoalan-persoalan agama pada orang yang diwawancarai atau diteliti kecuali kalau ia sendiri beriman dan berefleksi, bukan saja pada situasi sementara penelitian dilakukan, tetapi juga di luar konteks penelitian yaitu dalam hidup sehari-hari. Kalau si peneliti bukan orang yang beragama, akhirnya ia hanya sanggup mengkonstatir ungkapanungkapan kepercayaan dan gejala-gekala agamaniah, tetapi bukan iman atau agama itu sendiri. Mungkin dalam arti tertentu sosiologi dan psikologi sudah puas dengan menemukan gejala-gejala tersebut. Tetapi justru dalam penelitian agama, ungkapan-ungkapan dan gejala-gejala itu tidak dapat diterima dengan face-value-nya. Dalam penelitian agama, refleksi perlu dijalankan. Penelitian agama tidak mungkin dilakukan kalau peneliti itu tidak tahu seluk-beluk persoalan pokok agama. Karena itu peneliti dan juga para pekerja lapangan dalam bidang agama itu sendiri harus beragama dan berefleksi atas agamanya. Dan di sinilah justru perbedaan antara penelitian agama dengan sosiologi agama dan psikologi agama. ${ }^{37}$

Di tempat lain, Mukti Ali kembali menekankan pentingnya peneliti agama yang beragama, sebagaimana pernyataannya berikut ini:

Dalam konsep penelitian agama ini refleksi sudah mulai dijalankan dalam lapangan penelitian.Tapi bagaimana mungkin kalau pekerja lapangan, pewawancara misalnya tidak tahu apa-apa tentang persoalan pokok agama? Kalau begitu orang semacam ini tidak dapat dipakai dalam proses penelitian agama. Karena itu kami menekankan suatu tuntutan bahwa si penyelidik dan juga para pekerja lapangan dan sebagainya sendiri beragama dan berefleksi atas agamanya. ${ }^{38}$

\footnotetext{
${ }^{35}$ Ali, "Penelitian Agama (Suatu Pembahasan tentang Metode dan Sistem)", 28-30.

${ }^{36}$ Ali, "Penelitian Agama di Indonesia", 28.

${ }^{37}$ Ali, "Penelitian Agama di Indonesia", 27.

${ }^{38}$ Ali, "Penelitian Agama (Suatu Pembahasan tentang Metode dan Sistem), 32.
} 
Baginya, peneliti merupakan subjek yang dapat saja terlibat dalam penelitian imannya sendiri. Oleh karena itu, objektivitas atau netralitas, menurutnya, tidaklah merupakan kriteria utama dan satu-satunya dalam proses penelitian agama, tetapi penilaian subjektif juga merupakan unsur penting dan merupakan kriteria yang menentukan dalam proses penelitian. ${ }^{39}$ Atas dasar ini dalam pandangan Mukti Ali adanya unsur refleksi agamis peneliti yang bersifat subjektif tidak menghalangi dan mengurangi nilai ilmiah penelitian agama. Tetapi justru dengan refleksi semacam ini fenomena keagamaan dapat dipahami dengan bahasa yang lebih tepat.

Selain mensyaratkan peneliti harus beragama dan mampu melakukan refleksi agamis terhadap fenomena keagamaan yang diteliti, Mukti Ali juga memberikan kriteria atau kelengkapan tambahan khusus bagi peneliti yang ingin meneliti atau memahami agama lain selain agama yang dipeluknya. Pertama, kelengkapan yang bersifat intelektual, yaitu kelengkapan informasi tentang agama yang diteliti dan penguasaan bahasa agama yang diteliti. Jika peneliti tidak menguasai bahasa agama atau kitab suci yang bersangkutan dapat dilakukan melalui terjemahannya. Kedua, kondisi emosional yang cukup, yaitu berusaha memahami agama orang lain harus melibatkan "feeling", perhatian dan partisipasi. Untuk menimbulkan rasa partisipasi, peneliti sebaiknya memilik pengalaman bergaul dengan penganut agama yang diteliti. Pengalaman bergaul ini akan membantu peneliti memahami agama penganut agama yang diteliti. Ketiga, kemauan. Peneliti harus memiliki kemauan untuk memahami agama orang lain dengan tujuan dan orientasi yang konstruktif. Keempat, pengalaman, yaitu pengalaman yang luas mengenai watak manusia. Pengalaman semacam ini akan menambah kualifikasi peneliti untuk memahami agama yang bukan agamanya sendiri, karena ia dapat menghubungkan pikiran-pikiran orang dalam berbagai macam perilaku, perasaan dan cara berpikir, terutama dalam cara orang beragama. ${ }^{40}$

Terkait dengan tahapan penelitian, pada intinya, menurut Mukti Ali, metode penelitian agama sebaiknya diwarnai dan mengandung sifat keagamaan.yakni bahwa penelitian agama itu bertitik tolak dari permasalahan agama dan bahwa proses diagnosa dan prognosa diarahkan oleh salah satu skema evaluasi yang diambil dari agama. ${ }^{41}$ Aplikasi pendekatan ini dalam penelitian agama secara operasional, menurut Mukti Ali, dilakukan melalui tahapan berikut: (1) dengan seksama mengamati fakta-fakta, (2) menentukan di mana letak kemungkinan-kemungkinan yang paling menonjol, artinya mencoba memahami apakah arti fakta-fakta itu, (3) berdasarkan pemahaman yang rasional pada tahap 1 dan 2 mencoba melihat dari segi cahaya agama, dan (4) menilai dalam cahaya agama pelaksanaan konkret sesuai dengan situasi historis. ${ }^{42}$ Keempat tahapan ini jika dilihat dari perspektif pendekatan scientificcum doctriner, sebagaimana akan dibahas pada bagian berikutnya, menunjukkan bahwa tahapan 1 dan 2 menggunakan metode scientific (tahap penyaringan data) sedang tahapan 3 dan 4 menggunakan metode doktriner (tahap interpretasi).

Aspek berikutnya yang juga dikemukakan oleh Mukti Ali adalah tentang tiga tipe penelitian yang tepat untuk digunakan dalam penelitian agama dengan menggunakan metode ilmu-ilmu sosial. Pertama, tipe penelitian deskriptif. Di sini ia mengemukakan tiga corak penelitian dalam ilmu-ilmu sosial, yaitu deskripsi, eksplorasi dan verifikasi. Pembeda ketiga corak penelitian ini terletak pada peranan hipotesa. Hipotesa tidak dipergunakan dalam penelitian deskriptif; hipotesa baru dibentuk pada akhir penelitian pada penelitian eksplorasi; dan hipotesa merupakan titik tolak untuk diuji pada

\footnotetext{
${ }^{39}$ Ali, "Penelitian Agama (Suatu Pembahasan tentang Metode dan Sistem), 32.

${ }^{40}$ Ali, Ilmu Perbandingan Agama di Indonesia, 61-63.

${ }^{41}$ Ali, "Penelitian Agama di Indonesia", 28.

${ }^{42} \mathrm{Ali}$, "Penelitian Agama di Indonesia", 26.
} 
penelitian verifikatif. Menurutnya, penelitian agama tidak bermaksud mengembangkan teori-teori baru, tetapi ingin melukiskan salah satu kelompok sosial dan gejala-gejala dalam masyarakat agama. Atas dasar ini ia berpendapat bahwa tipe penelitian deskriptif yang tidak menggunakan hipotesa lebih cocok untuk penelitian agama. ${ }^{43}$ Kedua, grounded theory (teori berakar). Penelitian ini tidak melalui proses pengujian hipotesis yang telah dibentuk sebelumnya kemudian diverifikasi, tetapi penelitian sendiri berusaha memunculkan teori dari dalam penelitian. Menurutnya, tipe penelitian ini disamping mencukupi tuntutan-tuntutan kekhasan penelitian agama juga sesuai dengan perkembangan ilmuilmu sosial modern. Ketiga, action research. Tipe penelitian ini merupakan kombinasi aksi sosial (memengaruhi dan mengubah keadaan sosial) dengan penelitian; dengan kata lain kombinasi antara bertindak dan mengetahui. Penelitian semacam ini perlu digunakan karena menurutnya, keterlibatan si peneliti sebagai orang yang beragama dan yang berefleksi dalam lapangan agama menuntut tipe riset semacam ini. ${ }^{44}$

Pada aspek metode yang digunakan dalam penelitian agama yang menggunakan metode ilmiah yang biasanya digunakan dalam ilmu-ilmu sosial, Mukti Ali mengemukakan beberapa metode atau teknik yang dapat dijadikan bahan pertimbangan untuk digunakan dalam penelitian agama. Beberapa metode atau teknik itu adalah dokumen pribadi, questionnaire, wawancara, public opinion poll, obersarvasi, dan lainnya. Dokumen pribadi dapat diteliti dengan menggunakan pendekatan nomothetic jika jumlahnya banyak dan pendekatan idiographic jika dokumennya hanya satu atau sedikit. Pendekatan idiographic juga memiliki bobot ilmiah jika didukung oleh sumber-sumber lain. Questionnaire, interview dan public opinion poll yang bersifat baku atau terbuka dapat dipertimbangkan untuk dipergunakan dalam penelitian agama. Sedangkan untuk observasi (sosiologis dan antropologi) disarankan untuk menggunakan observasi partisipan. Metode lain yang juga disarankan untuk dipertimbangkan penggunaannya adalah metode perbandingan agama, pendekatan genetic (meneliti pertumbuhan agama), grafik dan statistik. ${ }^{45}$

Gagasan-gagasan metode atau teknik penelitian yang disarankan Mukti Ali di atas menunjukkan bahwa ia mendukung penggunaan pendekatan dan metode kualitatif maupun kuantitatif dalam penelitian agama. Istilah nomothetic, statistik dan penggunaan teknik questionnaire, public opinion poll termasuk dalam tradisi penelitian kuantitatif, sementara istilah idiographic danteknik observasi partisipan merupakan bagian dari tradisi kualitatif.

\section{Pendekatan Scientific-cum-Doktriner: Metode Sintesis dalam Penelitian Agama}

Pada bagian awal bukunya Ilmu Perbandingan Agama di Indonesia, Mukti Ali menyebutkan bahwa diperlukan pendekatan multidisipliner dan nonkonvensional dalam studi agama dan memisahkan studi ini dari penilaian-penilaian teologis. ${ }^{46}$ Pemikiran ini didasarkan pada kenyataan bahwa terdapat sejumlah varian pemikiran terkait aplikasi metode dalam studi agama yang perlu dicarikan titik temunya. Dalam hal ini, Mukti Ali mengemukakan tiga varian dalam penggunaan metode studi agama. Pertama, aliran yang menekankan bahwa cara untuk mendekati agama itu semestinya sui generis dan tidak bisa dihubungkan dengan metode-metode dalam bidang ilmu pengetahuan lain. Kedua, aliran yang menyatakan bagaimanapun dan apapun masalah yang diteliti metode yang sah untuk dipergunakan

${ }^{43}$ Ali, "Penelitian Agama di Indonesia", h. 27-28; Lihat juga Ali, "Penelitian Agama (Suatu Pembahasan tentang Metode dan Sistem)", 32-33.

${ }^{44}$ Ali, "Penelitian Agama (Suatu Pembahasan tentang Metode dan Sistem)", 32 dan 36.

${ }^{45} \mathrm{Ali}$, "Penelitian Agama di Indonesia", 29-30.

${ }^{46} \mathrm{Ali}$, Ilmu Perbandingan Agama di Indonesia, 2-3. 
adalah metode ilmiah. Istilah "ilmiah" di sini dipergunakan dalam arti ganda: dalam arti sempit, ia menunjukkan metode-metode yang dipergunakan pada ilmu alam; dan dalam arti yang luas, ia menunjuk pada suatu prosedur yang bekerja dengan disiplin yang logis dan utuh dari premis-premis yang jelas. Ketiga, aliran yang menghendaki adanya metode sintesis dalam studi agama, yakni perpaduan antara metode sui generis dan metode ilmiah. Aliran kedua yang berpihak pada metode ilmiah dalam studi agama menentang adanya pluralisme dan dualisme metode semacam ini. Mukti Ali memilih metode yang ketiga, yakni agama harus diteliti dengan menggunakan metode gabungan.Kedua metode sebelumnya menurutnya memiliki kekurangan. Dia mengemukakan bahwa banyak penulis teologi dan filsafat telah membuktikan tidak cukupnya pendekatan ilmiah yang sempit terhadap studi agama. Menurutnya, banyak sarjana yang terkemuka mempertanyakan absahnya penerapan metode-metode dan teknik eksperimental, kuantitatif dan penelitian kausal terhadap dunia spiritual.Agar metode studi agama tepat maka metode yang digunakan harus sesuai dengan objek yang diteliti, yakni agama. Implikasinya, fenomena individu, hakikat nilai, dan arti kebebasan harus diakui. Peneliti yang tidak memberikan konsesi kepada metode yang mengakomodasi aspek ini akan bersikap tertutup terhadap kehidupan keagamaan pribadi. ${ }^{47}$

Selanjutnya, Mukti Ali mengemukakan beberapa metode atau pendekatan yang selama ini telah digunakan dalam studi agama. Pertama, pendekatan sejarah, yaitu pendekatan yang berusaha untuk menelusuri asal-usul dan pertumbuhan ide-ide agama dan lembaga-lembaganya berdasarkan periodeperiode dari perkembangan tertentu serta berusaha memahami kekuatan-kekuatan yang ada pada agama itu dalam periode tertentu dalam menghadapi berbagai masalah. Para ahli sejarah agama seringkali menggunakan penelitian-penelitian arkeologis dan filologis dalam mengkaji agama. Mereka melakukan studi yang diteliti terhadap monumen-monumen dan bukti-bukti literer dari masa lalu. Kedua, pendekatan psikologis yang digunakan oleh para ahli psikologi, yaitu pendekatan yang berusaha memahami sisi dalam dari pengalaman agama di mana dan kapan saja pengalaman itu terjadi. Pendekatan ini juga berusaha memahami perasaan indidividu dan kelompok berserta dengan dinamikanya. Ketiga, pendekatan sosiologis, pendekatan ini semula menggunakan metode sosiologi umum yang dicetuskan oleh ahli sosiologi yang kemudian dikoreksi oleh pendiri sosiologi agama. Keempat, pendekatan fenomenologi agama yang menurut Mukti Ali sendiri merupakan metode baru dalam studi agama. Pendekatan ini bertujuan untuk melihat ide-ide agama, amalan-amalan, dan lembaga-lembaganya dengan mempertimbangkan tujuannya tanpa menghubungkannya dengan teoriteori filosofis, teologis, metafisis atau psikologis. Dengan mengikuti pandangan Scheler, Ali menjelaskan bahwa metode fenomenologi diaplikasikan dalam studi agama dengan cara membiarkan manifestasimanifestasi pengalaman agama untuk bicara bagi dirinya sendiri daripada memaksakan manifestasimanifestasi itu dimasukkan pada suatu skema yang sudah ditentukan lebih dahulu. Pendekatan fenomenologis memiliki prosedur ganda, yaitu epoche (penghentian sementara dari semua usaha untuk mengetahui kebenaran) dan eiditic vision (mencari esensi yang dalam fenomena agama). Kelima, metode tipologis yang merupakan jembatan antara penelitian empiris dan normatif. Fenomena yang diberikan oleh sejarah, psikologi dan sosiologi agama harus diatur. Untuk hal ini diperlukan kategori-kategori tipologis. Penyusunan tipe-tipe ini dimaksudkan untuk memberikan pemahaman yang lebih baik tentang sejarah agama. Tipe-tipe mitos, teologi, peribadatan, karisma agama, kepemimpinan, pengelompokan dan otoritas agama merupakan beberapa tipe yang dikaji melalui pendekatan tipologis. ${ }^{48}$

${ }^{47}$ Ali, Ilmu Perbandingan Agama di Indonesia, 74-76.

${ }^{48} \mathrm{Ali}$, Ilmu Perbandingan Agama di Indonesia, 76-79. 
Beberapa pendekatan atau metode yang telah dikemukakan di atas menurut Mukti Ali sendiri belum cukup untuk memahami agama dengan baik. Pendekatan ilmiah semacam itu harus dilengkapi dengan pendekatan dogmatis sebagaimana pernyataannya berikut ini:

Berpegang pada pendirian tentang keharusan adanya pendekatan sintesis, maka kami berpendapat bahwa pendekatan-pendekatan ilmiah, yaitu pendekatan-pendekatan historis, arkeologis, filologis, sosiologis, fenomenologis, tipologis dan sebaganya, harus disertai dengan pendekatan yang khas agama yang "dogmatis". Dengan itu maka pendekatan "religio-scientific" atau scientific-cum-doktrinair" atau "ilmiah-agamis" harus kita pergunakan dalam mendekati agama itu. ${ }^{49}$

Terdapat perbedaan titik berangkat dan hasil dari studi agama dengan pendekatan ilmiah dan ilmu agama yang religio-scientific (ilmiah-agamis). Sosiologi agama sebagai contoh, meski menggarap data yang sama dan mungkin juga menggunakan metode yang sama, sosiologi agama dengan pendekatan ilmiah hanya melihat data secara sosiologis sedangkan sosiologi agama yang berangkat dari disiplin ilmu agama melihat data secara religio-scientific (ilmiah-agamis). ${ }^{50}$

Menurut Ali, bukanlah masalah sederhana untuk mengartikan apa yang dimaksud dengan melihat data secara ilmiah-agamis. Ilmu agama (religionswissenschaft) berbeda dengan disiplin-disiplin normatif karena tidak mempunyai tujuan spekulatif dan juga tidak berangkat dari metode deduktif yang apriori. Meski prinsip kajian ilmu agama adalah bersifat deskriptif tetapi penelitiannya harus diarahkan untuk mencari arti dari fenomena agama. Ali tampaknya setuju dengan pernyataan Profesor Eliade yang dikutipnya, "Untuk berusaha memahami esensi fenomena semacam ini dengan alat fisiologi, psikologi, sosiologi, ekonomi, bahasa, seni, atau studi-studi lainnya, adalah palsu: ia kehilangan satu-satunya elemen-elemen yang unik dan tidak bisa ditinggalkan dalam fenomena itu—elemen kesucian". Menurut Ali, Eliade sadar bahwa tidak ada fenomena yang eksklusif agamis. Tetapi, Ali setuju bahwa agama tidak bisa hanya dijelaskan dengan menggunakan perspektif fungsi sosial, linguistik atau ekonomis. ${ }^{51}$

Tidak hanya dalam studi agama, Mukti Ali juga menyarankan agar metode sintesis juga digunakan dalam studi Islam. Menurutnya, satu metode saja tidak cukup untuk mempelajari Islam, karena Islam bukan agama yang monodimensi.Mempelajari Islam dengan berbagai aspeknya tidaklah cukup dengan menggunakan metode ilmiah saja, demikian pula tidak bisa hanya secara doktriner. Tetapi pendekatan ilmiah dan doktriner harus digunakan bersama.Ahli-ahli ilmu pengetahuan (termasuk orientalis), menurutnya, mendekati Islam dengan menggunakan metode ilmiah saja. Dampaknya, meski menarik tetapi sebenarnya mereka tidak memiliki pemahaman secara utuh. Mereka hanya mengetahui aspek eksternalnya saja dari Islam. Sebaliknya, ulama terbiasa memahami Islam dengan cara doktriner dan dogmatis, yang sama sekali tidak berhubungan dengan realitas yang ada di masyarakat sehingga interpretasinya tidak dapat diterapkan dalam masyarakat. Karena itu, pendekatan ilmiah-cum-doctriner harus dipergunakan, pendekatan scientific-cum-suigeneris harus diterapkan. Inilah yang dimaksud metode sintesis. ${ }^{52}$

${ }^{49}$ Ali, Ilmu Perbandingan Agama di Indonesia, 79. Mukti Ali sendiri mengakui bahwa pendekatan ini tidaklah orisinal, karena ia berasal dari Joachim Wach yang kemudian ditransfer menjadi pendekatan ilmiah cum doctriner. Masalah ini menurut Ali belum selesai, karena masalahnya adalah bahwa orang yang mendekati agama adalah masalah kebenaran.Kebenaran yang dicari Ilmu Perbandingan Agama bukanlah kebenran objektif, juga bukan kebenaran subjektif. Kebenaran yang dicari oleh Ilmu Perbandingan Agama adalah phenomenological truth, yaitu kebenaran sebagaimana adanya yang ia miliki dan kita rela dia memiliki kebenaran itu. Lihat "Jawaban Prof. Dr. H. A. Mukti Ali” dalam Tim Redaksi INIS, Ilmu Perbandingan Agama di Indonesia, 125-126.

${ }^{50}$ Ali, Ilmu Perbandingan Agama di Indonesia, 69-70. Penggunaan pendekatan religio-scientific yang dikemukakan oleh A. Mukti Ali menunjukkan akan pengaruh Wach dalam pendekatan sientific-cum-doctrinaire yang digagasnya. Menurut Joachim Wach, sebagaimana dikemukakan oleh Romdon, mensyaratkan semua objek forma studi perbandingan agama harus bersifat religio scientifical. Religio-scientifical mengkaji agama sebagai agama yang merupakan gejala kemanusiaan yang melibatkan keadaan manusia secara bulat, perasaannya, pikirannya, kemauannya, dan biasanya agama itu dikaitkan dengan hal-hal yang dianggap kudus (sacred) oleh pemeluknya.Sifat dari pendekatan religio scientifical ini adalah memperhatikan sifat agama yang merupakan concern manusia sebagai totalitas dan mengandung elemen sacred dan mengkajinya dengan pemahaman simpatik, sikap kritis, dan semangat ilmiah. Lihat Romdon, Metodologi Ilmu Perbandingan Agama Suatu Pengantar Awal (Jakarta: PT RajaGrafindo Persada, 1996$)$, 4-6.

${ }^{51}$ Ali, Ilmu Perbandingan Agama, 70. 
Di tempat lain, sebagaimana yang dikemukakan oleh A. Singgih Basuki, Mukti Ali mengemukakan tiga pendekatan dalam studi Islam. Pertama, pendekatan scientific, yaitu mendekati agama secara ilmiah. Ia menolak pendekatan ini jika hanya digunakan secara tunggal karena dianggap tidak cocok. Kedua, pendekatan dogmatis, yaitu mendekati agama didasarkan pada pernyataan Alquran dan hadis. Ketiga, pendekatan ilmiah plus doktriner, seperti secara sosiologis tetapi juga Qur'ani, secara antropologi tetapi juga disertai penjelasan hadis, secara filosofis dan Qur'ani. Inilah pendekatan sintesis atau integral yang dikembangkan dan dinilai ideal oleh Mukti Ali. ${ }^{53}$

Untuk memahami pendekatan ini, beberapa dimensi pendekatan scientific-cum-doctriner Mukti Ali sebagaimana yang dijabarkan oleh Waryani Fajar Riyanto (dengan beberapa modifikasi) mungkin sedikit banyaknya dapat membantu melihat beberapa sisi dari pendekatan ini, sebagaimana terlihat pada tabel berikut: ${ }^{54}$

\begin{tabular}{|l|l|}
\hline \multicolumn{2}{|c|}{ Dimensi Pendekatan Scientific-cum-Doctriner Mukti Ali } \\
\hline Metodologi & Sintesis (scientific-cum-doctriner) \\
\hline Sifat dasar & Saintifik-doktriner (ilmiah-dogmatis) \\
\hline Sifat tcmuan & Objcktif-cum-subjcktif (phenomenological truth) \\
\hline Bentuk & Diadik \\
\hline Pola Ganda & Al-Qur`an dan scjarah Islam (normatif-historis) \\
\hline Klasifikasi Ilmu & Keilmuan agama, social sciences, dan nalural sciences \\
\hline Era & Modcrn \\
\hline Gagasan Kajian Agama & Comparalive Religion (Intra-Fakultasisasi) \\
\hline Teori Harmoni & Agree in Disagreement "Tolerance" \\
\hline Mazhab & Islamisasi Ilmu \\
\hline
\end{tabular}

Apa yang dikemukakan oleh Mukti Ali menurut Amin Abdullah menunjukkan bahwa penelitian empiris fenomena keagamaan tidak bisa berdiri sendiri. Ia masih perlu memahami aspek "internal" agama untuk memahami dimensi normativitasnya. Inilah yang disebut oleh Mukti Ali dengan istilah "scientific cum doctriner". ${ }^{55}$ Sementara menurut Dadang Kahmad, metode sintesis ini merupakan metode alternatif yang menjadi jalan tengah antara metode sui generic dan metode ilmiah atau penggabungan antara metode ilmiah dengan metode teologi. Pada metode ini doktrin dan bahasa agama digunakan sebagai 'alat analisis' untuk memahami fakta-fakta keagamaan. ${ }^{56}$ Dengan demikian, unsur doktriner atau dogma agama dalam pendekatan scientific-cum-doctriner tidak dimaksudkan untuk melakukan penghakiman atas perilaku keagamaan dan doktrin agama lain. Demikian pula tidak untuk menunjukkan superioritas atau imperioritas antara satu agama dengan agama lainnya. Tetapi aspek doktriner digunakan untuk memahami fenomena keagamaan dengan merujuk pada doktrin agama yang selaras dengan fenomena keagamaan itu agar dapat dipahami berdasarkan bahasa agama.

Alef Theria Wasim, sebagaimana yang dikutip oleh Waryani Fajar Riyanto memandang bahwa masih ada beberapa hal yang perlu dikembangkan terkait ide scientific-cum-doctriner. Pertama, meneruskan

${ }^{52}$ A. Mukti Ali, "Metodologi Ilmu Agama Islam" dalam Taufik Abdullah dan Rusli Karim (ed.), Metodologi Penelitian Agama Sebuah Pengantar (Yogyakarta: PT. Tiara Wacana Yogya, 1991), 47-48.

${ }^{53}$ Basuki, Pemikiran Keagamaan A. Mukti Ali, 98.

${ }^{54} \mathrm{Tabel}$ ini diolah dan dimodifikasi dengan membuang satu kolom yang berisi tentang metode sirkular-hermeneutik Amin Abdullah.Tabel ini sebenarnya berisi perbandingan antara metode scientific-cum-doctriner dari Mukti Ali dan metode sirkularhermeneutik dari Amin Abdullah.Lihat tabel 35 yang terdapat pada Riyanto, Integrasi-Interkoneksi Keilmuan, 652.

${ }^{55}$ Amin Abdullah, Studi Agama: Historisitas atau Normativitas?(Yogyakarta: Pustaka Pelajar, 1996), 57.

${ }^{56}$ Dadang Kahmad, Metode Penelitian Agama Perspektif Ilmu Perbandingan Agama (Bandung Pustaka Setia, 2000), 82-83. 
dan mengisi ide tentang scientific-cum-doctriner. Maksud ide tersebut masih perlu dikembangkan, seperti cara kerja dan sebagainya. Kedua, mencari sintesa baru lagi untuk dikembangkan untuk mengisi konsep scientific-cum-doctriner. ${ }^{57}$ Menurut Basuki, Mukti Ali sendiri mengakui bahwa langkah operasional metode sintesis belum dirumuskan secara pasti. Pembahasan metode ini masih memerlukan kajian lebih lanjut yang harus melibatkan ilmuwan agama dan sosial. ${ }^{58}$ Karena aspek operasional metode ini belum dirumuskan secara jelas, tidak mengherankan jika hasil studi atau penelitian agama yang menggunakan metode ini juga dipertanyakan keberadaannya. Tidak mengherankan ketika Mujahid Abdul Manaf membahas metode sintesis ini menyatakan bahwa contoh dari aplikasi pendekatan ini masih terlalu sulit untuk ditemukan. ${ }^{59}$

\section{Penutup}

Paparan yang telah dikemukakan di atas menunjukkan bahwa dalam perspektif Mukti Ali penelitian agama harus menggunakan metode ilmiah yang dilakukan secara objektif tanpa melibatkan unsur apologis-polemis di dalamnya. Metode ilmiah yang digunakan dapat saja memakai metode ilmiah yang digunakan dalam ilmu-ilmu sosial atau melakukan kerjasama dengan ilmu-ilmu sosial dalam mengkaji agama. Namun, ia mengingatkan bahwa pemakaian metode ilmiah dan ilmu-ilmu sosial saja tidak cukup untuk memahami fenomena keagamaan. Refleksi agamis dalam memahami fenomena keagamaan harus dilibatkan agar interpretasi terhadap fenomena itu dapat selaras dengan bahasa agama.

Dalam melakukan penelitian agama, Mukti Ali menekankan faktor peneliti sebagai faktor yang lebih penting daripada metode. Ia tidak hanya menyaratkan agar peneliti memiliki sikap ilmiah, integritas pribadi dan penguasaan metodologi, tetapi juga mengharuskan agar peneliti agama adalah orang yang beragama pula. Baginya, peneliti yang tidak beragama tidak akan mampu memahami fenomena agama dengan tepat. Selain itu, ia juga mengemukakan beberapa kelengkapan tambahan lagi khusus bagi peneliti yang ingin meneliti agama orang lain, yaitu kelengkapan intelektual (informasi dan kemampuan bahasa), kondisi emosional yang cukup, kemauan yang positif untuk memahami agama orang lain, dan pengalaman yang luas dalam memahami watak manusia.

Tipe penelitian yang cocok dan paling tepat untuk penelitian agama menurut Mukti Ali adalah penelitian deskriptif (tanpa hipotesa), penelitian grounded theory (teori berakar), dan action research. Sementara untuk aspek metode dan teknik penelitian dapat saja menggunakan metode kuantitatif yang bersifat nomothetic atau metode penelitian kualitatif yang bersifat idioghrafic dengan segala prosedur dan tekniknya masing-masing. Bisa juga menggunakan metode sejarah, metode fenomenologi, metode tipologis, metode perbandingan, metode genetik dan lain sebagainya. Hanya saja, Mukti Ali menekankan bahwa metode penelitian agama sebaiknya diwarnai dan mengandung sifat keagamaan. Karena itulah baginya, tidak cukup hanya menggunakan metode-metode sebagaimana yang disebutkan tadi. Untuk itu ia menawarkan metode sintesis dalam meneliti agama, yaitu metode yang melibatkan unsur dogmatis di dalamnya selain metode ilmiah.

Menurutnya, penelitian agama tidak bisa hanya menggunakan metode dan pendekatan ilmiah saja atau pendekatan doktriner saja. Keduanya menurutnya harus disintesiskan agar ditemukan hasil kajian yang holistik dan integral yang bersifat religio-scientific dalam memahami fenomena keagamaan.

\footnotetext{
${ }^{57}$ Riyanto, Integrasi-Interkoneksi Keilmuan, 651.

${ }^{58}$ Basuki, Pemikiran Keagamaan A. Mukti Ali, 101.

${ }^{59}$ Mujahid Abdul Manaf, Ilmu Perbandingan Agama (Jakarta: PT RajaGrafindo Persada, 1994), 35-36.
} 
Inilah yang dinamakan oleh Mukti Ali sebagai pendekatan scientific-cum-doctrinaire. Terlepas dari kelebihan dan kekurangannya, pendekatan ini merupakan salah satu pendekatan alternatif dan model penelitian agama yang dapat diaplikasikan secara operasional dalam penelitian agama. Karena rumusan operasional dan bentuk konkret pendekatan ini masih dipertanyakan, para peneliti agama dapat "berijtihad" sendiri untuk mencari rumusan operasional pendekatan ini dalam meneliti agama dan menggunakannya dalam penelitian.

\section{DAFTAR PUSTAKA}

Abdullah, M. Amin. Studi Agama: Historisitas atau Normativitas? Yogyakarta: Pustaka Pelajar. 1996.

Ali, A. Mukti. Ilmu Perbandingan Agama: Sebuah Pembahasan tentang Metodos dan Sistema. Yogyakarta: PT al-Falah. 1975.

-. Ilmu Perbandingan Agama di Indonesia. Bandung: Mizan. 1996.

—. "Penelitian Agama di Indonesia" dalam Mulyanto Sumardi (ed.). Penelitian Agama Masalah dan Pemikiran. Jakarta: Sinar Harapan. 1982.

—. "Metodologi Ilmu Agama Islam" dalam Abdullah, Taufik dan Rusli Karim (ed.). Metodologi Penelitian Agama Sebuah Pengantar. Yogyakarta: PT. Tiara Wacana Yogya. 1991.

- "Penelitian Agama (Suatu Pembahasan tentang Metode dan Sistem)" dalam A. Makmur Makka (ed.), 70 Tahun B.J. Habibie. Jakarta: Pustaka CIDESINDO. 1996

Basuki, A. Singgih. Pemikiran Keagamaan A. Mukti Ali.Yogyakarta: Suka Press. 2013.

Damami, Muhammad, dkk. "Prof. Dr. H. A. Mukti Ali, M.A.” dalam Lima Tokoh LAIN Sunan Kalijaga Yogyakarta. Yogyakarta: Suka Press. 2000.

Daya, Burhanuddin dan Herman Leonard Beck (ed). Ilmu Perbandingan Agama di Indonesia dan Belanda. Jakarta: INIS. 1992.

Djam'annuri (ed.). 70 Tahun H. A. Mukti Ali: Agama dan Pembangunan. Yogyakarta: IAIN Sunan Kalijaga Press. 1993.

Handrianto, Budi. 50 Tokoh Islam Liberal Indonesia Pengusung Sekularisme, Pluralisme, dan Liberalisme Agama.Jakarta: Hujjah Press. 2007.

Kahmad, Dadang. Metode Penelitian Agama Perspektif Ilmu Perbandingan Agama. Bandung: CV Pustaka Bandung. 2000.

Manaf, Mujahid Abdul. Ilmu Perbandingan Agama. Jakarta: PT Raja Grafindo Persada. 1994.

Rahmadi, dkk. Dinamika Pemikiran Sarjana Muslim tentang Metodologi Studi Agama di Indonesia. Kajian terhadap Literatur Terpublikasi Tahun 1964-2012. Banjarmasin: IAIN Antasari Press. 2014.

Riyanto, Waryani Fajar. Integrasi-Interkoneksi Keilmuan: Biografi Intelektual M. Amin Abdullah (1953-...) Person, Knowledge, and Institution (Buku Pertama). Yogyakarta: Suka Press. 2013.

—. Studi Islam Indonesia (1950-2014).Yogyakarta: Kurnia Kalam Semesta. 2014. 
Romdon. Metodologi Ilmu Perbandingan Agama Suatu Pengantar Awal. Jakarta: PT RajaGrafindo Persada. 1996.

Sudjangi (ed.). Kajian Agama dan Masyarakat 15 Tabun Badan Penelitian dan Pengembangan Agama, 19751990. Jakarta: Departemen Agama RI. 1992.

Tim Redaksi. Ilmu Perbandingan Agama di Indonesia Beberapa Permasalahan. Jakarta: INIS. 1990. 